A Journal of Culture, English Language, Teaching \& Literature ISSN 1414-3320 (Print), ISSN 2502-4914 (Online)

Vol. 20 No.1; June 2020

Copyright (@) Soegijapranata Catholic University, Indonesia

Applying Skimming Strategy in Teaching Reading Descriptive Text

Vemby Ari Sandi

English Education Department, Surabaya State University

email: vembyarisandi@yahoo.co.id

Received: 20-05-2016

Accepted: 28-02-2017

Published: 09-06-2020 


\title{
Applying Skimming Strategy in Teaching Reading Descriptive Text
}

\section{Vemby Ari Sandi}

vembyarisandi@yahoo.co.id

English Language Education Department, Faculty of Language and Art, Universitas Negeri Surabaya, Indonesia

\begin{abstract}
Reading is an important activity to enrich knowledge. However, it is considered as a difficult skill to learn. There are many students facing difficulties in comprehending the content of the reading text, including descriptive text. A strategy which can solve such problems is needed. Skimming strategy is the strategy which enable students to quickly find the main idea and relevant information of the text. Based on those reasons, the research questions are proposed as follows: (1) How can skimming strategy be implemented in teaching reading descriptive texts? and (2) How can the second year students' reading comprehension ability be improved using skimming strategy? This study used two research methods. Those were qualitative and quantitative research design. They were collected to prove the implementation and the significant improvement by using skimming strategy. Both numeric information and the real observation were evaluated to gain clear and strong data. The researcher acted as the observer to see the process of teaching and learning descriptive texts in three stages. The results of the research showed that the teacher and students implemented four steps of skimming strategy, which are: (1) read the first several paragraph; (2) leave out material; (3) find the main ideas; (4) read fast. The t-test of this research was also calculated to see whether there was a significant difference between control and experimental class and the mean was also measured to see the students' improvement score. The mean score of experimental class was better than the mean score of control class. However, the t-test result showed that there was no significant difference between experimental and control class.
\end{abstract}

Key words: skimming strategy, teaching reading descriptive texts 


\begin{abstract}
Abstrak: Membaca adalah kegiatan penting yang dapat meningkatkan pengetahuan. Namun, keterampilan tersebut dianggap sebagai keterampilan yang sulit dipelajari. Ada banyak siswa yang mengalami kesulitan dalam memahami isi teks bacaan, termasuk teks deskriptif. Oleh sebab itu, dibutuhkan strategi yang dapat menyelesaikan permasalahan tersebut. Strategi membaca cepat adalah strategi yang memudahkan siswa dengan cepat untuk menemukan ide pokok dan informasi relevan pada text. Berdasarkan alasan-alasan tersebut, pertanyaan penelitian ditujukan sebagai berikut: (1) Bagaimana strategi membaca cepat diterapkan dalam pengajaran membaca teks deskriptif dan (2) Bagaimana kemampuan memahami bacaan pada siswa kelas VIII dapat ditingkatkan menggunakan strategi membaca cepat. Studi ini menggunakan dua desain. Desain tersebut adalah desain penelitian kualitatif dan kuantitatif. Keduanya dikumpulkan untuk membuktikan penerapan dan peningkatan signifikan dengan menggunakan strategi membaca cepat. Baik informasi angka maupun pengamatan nyata dievaluasi untuk memperoleh data yang jelas dan kuat. Peneliti bertindak sebagai pengamat untuk melihat proses pengajaran dan pembelajaran teks deskriptif dalam tiga tahap. Hasil dari penelitian ini menunjukkan bahwa guru dan siswa menerapkan empat tahap strategi skimming sebagai berikut: (1) membaca awalan beberapa paragraf; (2) menyaring materi; (3) menemukan ide pokok; (4) membaca cepat. T-test pada penelitian ini juga dihitung untuk melihat apakah ada perbedaan signifikan antara kelas kontrol dan kelas eksperimen. Nilai rata-rata juga diukur untuk melihat peningkatan nilai siswa. Nilai siswa pada kelas eksperimen lebih baik dibandingkan dengan nilai siswa pada kelas kontrol. Akan tetapi, hasil t-test menunjukkan bahwa tidak ada perbedaan yang signifikan antara kelas eksperimen dan kelas kontrol.
\end{abstract}

Kata kunci: strategi membaca cepat, pengajaran membaca teks deskriptif.

\title{
INTRODUCTION
}

English has many purposes. Nowadays, many people enthusiastically learn, speak and communicate using English as their second language. Because English is known as an international language, it can be used for global career and world communication. It also brings us to get insight, information and knowledge about the world. Accessing to the internet is one of the tools which can be used for obtaining information from world.

According to Graddol (2000) many economist, cultural theorist and political scientist expected that there will be significance changes in the $21 \mathrm{st}$ 
century. The internet and related technologies are well increasingly developed and it automatically decrease the traditional patterns of communication. This shows that language and communication become a center role for human to communicate.

English is important to be learnt. It becomes the first foreign language taught at school and included in the curriculum. One of the subjects that is examined in the national examination test is English. Because of this, students have to prepare their English skill. To master English, students have to be able to grasp four language skills consisting of writing, listening, speaking and reading. This research will focus on reading skill.

Reading is an important activity to enrich knowledge. According to the the main competence of curriculum 2013 for eighth grade students, it is stated that students are expected to be able to comprehend and implement their knowledge (factual, conceptual and procedural) based on their curiosity on knowledge, technology, art, culture related with the phenomena and concrete event. It means that students are nowdays demanded to frequently read many kinds of information text. They are also demanded to think critically and creatively. They have to be able to implement their knowledge of what they have learnt into their daily life.

It is also reported in the basic competence of curriculum 2013 for eighth grade students in the aspect of reading, that students are expected to understand the purpose, the structure of text and grammatical features of oral and written descriptive text about person/animal/thing, very short and simple. Thus, students are not only hoped to be able to understand the written descriptive text, but they also should learn how to describe something orally in English. Therefore, the goal of teaching and learning English should be intended to develop students' language skill so that the graduates will be able to communicate and express ideas in English. All SMP (junior high school) students in Indonesia should be able to reach that objective, including SMPN 3 Waru Sidoarjo.

SMPN 3 Waru Sidoarjo is a school located in Jl. Jenderal S. Parman Waru Sidoarjo. That school recently implemented curriculum 2013. Both teachers and students hoped that it would bring positive effect for further development in all subjects, especially English. Teachers and students were expected to be able to communicate with English well.

Based on the interview data in SMPN 3 Waru, many students had difficulties in learning reading comprehension. Students had difficulties in 
grasping and understanding the content of text. In fact, English national examination test required students to comprehend kinds of text in short period of time. These conditions motivated the researcher to conduct experimental research to implement skimming strategy in reading descriptive text to the students of SMPN 3 Waru Sidoarjo.

Skimming is a worthy technique for students' reading comprehension. Skimming technique is reading process which focuses on how to decide the main idea of the text (Brown, 2004). The skimming technique can be applied for both short functional text and extensive text. By using the skimming technique, the students are expected to learn how to predict the topic of the text they have read. The students also know the text type/genre, the writer's perspective and the aim of the text.

Abdelrahman \& Bsarah (2014) also conducted research in Jordan. They found significant effect of speed reading strategies on developing reading comprehension. This research was conducted only on the second secondary literary male students. It was held in Al-Ashrafieh secondary school for boys. There were 21 students chosen randomly.

Citing Dyon \& Haselgrove (2000), Abdelrahman \& Bsarah (2014) informs that the time movement used in the process of skimming and scanning technique could gain the best comprehension. Scanning and skimming often completed with several types of question. The comprehension could be caught after reading both a normal and fast reading speed.

In addition, Windayani, Sundari \& Ariyanto (2014) also conducted a research on the use of skimming and scanning techniques to improve the reading comprehension achivement of grade $8 \mathrm{G}$ students of SMP Negeri 1 Ambulu Jember. The eighth grade students of MTs N1 Jember was passive in joining the reading class. They also had difficulties in reading comprehension skill. Their English test score was under the school standard score. After doing the skimming and scanning treatment using two cycles, there was significance changes. In the end of the research, it proved that teaching reading using skimming and scanning technique were applicable. It improved students' active participation in joining the reading comprehension class and students' reading comprehension achievement. That research used qualitative research design. Observation and reading comprehension test were used as the instrument to collect data.

Hutabarat (2012) also discovered positive effects of skimming technique on grade XI students' reading comprehension. This experimental research was 
held in SMA Methodist-7 Medan. Hutabarat conducted quantitative research design. Kuder Richardon formula was used to obtain the data.

Patmawati (2013) conducted a research on the implementation of skimming and scanning techniques in teaching reading. The English teacher and students of IX Class in SMPN 2 Lamongan were the subjects of this research. The objectives of this study were to describe how the teacher implements skimming technique in teaching reading comprehension, to describe how the teacher implements scanning technique in teaching reading comprehension and to explain how the implementation of skimming and scanning techniques improve student's reading comprehension. The using of qualitative data was observed in this study. Only one class was being observed. The result showed that students increase their ability in reading comprehension after treatment

According to the theories and previous studies mentioned above, skimming is very beneficial technique for students' reading comprehension ability. This technique will provide them how to comprehend text, find out the most important information of the text, and search main idea or other supporting data. Skimming is also used to enable the students' how to comprehend some types of reading genre including academic reading.

Previous studies analyzed the data using one research design. They also conducted skimming research on general reading comprehension, there were no specialized genre text observed. The sample were chosen by using lottery. While in this research in SMPN 3 Waru Sidoarjo, the sample were ten students. They were not selected by using lottery, but it was based on the level score including upper, middle and lower students. There were also no limitation sample on gender, both male and female are examined. In this research, skimming technique was focused on one genre text, it was descriptive text. The steps of skimming strategy was also distictive compared to the previous study. In this study, the theory of skimming stratgey was purposed by Fry (2000). Then, the mixed method research design was conducted.

There were two classes observed. The first was experimental class and the second was control class. Both qualitative and quantitative data were collected to prove the implementation and the significant improvement by skimming strategy. Both numeric information and the real observation were evaluated to gain clear and strong data. 
Sandi, V.A., Applying Skimming Strategy in Teaching Reading Descriptive Texts 189

\section{METHOD}

This research examined the implementation of skimming in junior high school. The research design used two studies. Those were qualitative and quantitative study. Qualitative data was used to answer the first research question of how skimming be implemented in teaching reading descriptive text. Observation as one of qualitative data technique was used to collect data and answer the first research question due to it could show the natural phenomenan of what was happening in the teaching and learning process. The major characteristics of qualitative research are:

1) Exploring a problem and developing a detailed understanding of a central phenomenon

2) Having the literature review play a minor role but justify the problem

3) Stating the purpose and research questions in a general and broad way so as to the participants' experiences

4) Collecting data based on words from a small number of individuals so that the participants' views are obtained

5) Analyzing the data for description and themes using text analysis and interpreting the larger meaning of the findings

6) Writing the report using flexible, emerging structures and evaluating criteria, and including the researchers' subjective reflexivity and bias. (Creswell, 2012)

Quantitative data was used to answer the second research question of how the second-year students' reading comprehension ability could be improved using skimming stategies. In this study, the students' reading test score was indicated whether there was improvement of students' reading comprehension ability before and after the treatment. Therefore, quantitative data was used to examine those numerical data. The major characteristics of quantitative research are:

1) Describing a research problem through a description of trends or a need for an explanation of the relationship among variables

2) Providing a major role for the literature through suggesting the research questions to be asked and justifying the research problem and creating a 
need for the direction (purpose statement and research questions or hypotheses) of the study

3) Creating purpose statements, research questions, and hypotheses that are specific, narrow, measurable and observable

4) Collecting numeric data from a large of people using instruments with preset questions and responses

5) Analyzing trends, comparing groups, or relating variables using statistical analysis, and interpreting results by comparing them with prior predictions and past research

6) Writing the research report using standard, fixed structures and evaluation criteria, and taking an objective, unbiased approach. (Cresswell, 2011)

Therefore, mixed method research design was implemented in this research. Both qualitative and quantitative data were examined. Miles, et. al. (2014) mentions that there are three levels in mixed-method designs. The first level is quantizing level. The second level is the comparison between qualitative data (for instance open-ended interview) and numerical data (for instance survey). The third is the mixture of case study, survey and experiments.

\section{RESULTS AND DISCUSSIONS}

The descriptions are presented in two sections. The first is the implementation of skimming in teaching reading descriptive text. The second is the improvement of the second-year students' reading comprehension ability by using skimming strategy.

\section{A. The Results of the Implementation of Skimming in Teaching Reading Descriptive Text}

Skimming is the strategy which focuses on how to decide the main idea of the text. By using skimming strategy, it is expected that students will be able to predict the topic of the text, the genre and the writers' perspective. There are several steps to do for skimming. The strategies are reading the first several paragraph, leaving out material, finding the main ideas and reading fast. 
There were four steps of skimming strategy that already implemented by the teacher in the experimental class. Those steps are reading the first several paragraph, leaving out material, finding the main idea and reading fast. Several conversations between students and teacher were already mentioned above and some student's task were also examined to see whether the students were able to answer questions by using skimming strategy.

\section{B. The Results of the Improvement of the Second-Year Students' Reading Comprehension Ability by Using Skimming Strategy}

In the control class from the first meeting until the last meeting, the teacher asked the students to read the text carefully. The teacher guided the students to focus on the prepared questions. However, in this control class, the teacher still did not explain anything about skimming strategy. He guided the students to find the answer without mentioning the steps of skimming strategy that was useful to find the relevant information quickly. Although the teacher did not explain the strategy, the teachers still asked the students to discuss the text that had been distributed and read. In last activity which was named as post-reading. The teacher reviewed the lesson. He told the students what had been learnt at that time. Before the teacher closed the meeting, the teacher asked the students to summarize the text. Teaching and learning process in the control class were distinctive compared with the teaching and learning process in the experimental class. In the control class, the students got no explanation about skimming strategy as the way to quickly find out the main idea and relevant information of the text. However, students did pretest and posttest as what the experimental did to see the significant differences between them.

The activities in the control class and experimental class were different. In the control class, the teacher did not explain the skimming strategy as what experimental class did. In short, the students of experimental class had information about skimming strategy. They were trained to quickly find the clue words of the text, the main idea, the topic, etc. As result, students in the experimental class had better understanding about the skimming strategy as the fast way to answer several reading comprehension questions.

The implementation of skimming strategy can improve reading comprehension ability which can be presented based on the students' test result, student's participation and observation. Pretest and posttest were held to see the significant improvement before and after the treatment. In this study, there were some formulas calculated. There were formulas to measure 
192 Celt: A Journal of Culture, English Language Teaching \& Literature, Volume 20, Number 1, June 2020, pp. 184 - 194

the mean, the reliability, the level difficulty of test, the standard deviation and the independent t-test. The formula of mean was to see the students' average score. The reliability was to know the coefficient correlation of the whole items. The level difficulty of test was to see the criteria of question which tested. The standard deviation was to measure the spread out of the numbers. And the independent t-test was to see whether there was significance result between control and experimental class.

After calculating the mean score both experimental and control class, there were significance difference which could be seen in quantitative result. The mean score for control class was 80.9 and the mean score for experimental class was 89 . It meant that the skimming treatment had shown its good result for their students' ability. However, by using SPSS, it was found that the value in the Sig. (2-tailed) is above 0.05, it meant that there was not a statistically significant differences in the mean scores for control and experimental class.

The success of the implementation of skimming strategy that had been proven in the result both from observation and test, it could be seen that the teacher's role was very prominent. When the teacher developed the skimming strategy in the whilst activity, the students also had high motivation to learn more about reading comprehension. It was due to the teacher mentioned several steps which could help the students to quickly find the important information on the text.

The reading class observation showed that in teaching and learning in experimental class was interesting. The students were also enthusiastic and excited to study in the class compared to the students in the control class. The students had increased their ability score in identifying the main idea of the text. They also had increased their participation score in discussion and responding the topic they had discussed.

\section{CONCLUSION}

Skimming is very useful strategy to comprehend many kinds of text. That strategy is proved succesfully by using several steps. Those are reading the first several paragraph, leaving out material, finding the main ideas, and reading fast. By comparing the result of control class and experimental class, it can be concluded that strategy has great impact to the students' reading ability. The students' score in experimental class is higher than students' score in 
control class. It meant that students who learnt skimming strategy had better score in reading comprehension test than the students who didnot learn skimming strategy.

In comparison to the students' reading achievement in the experimental class, it could be seen that the implementation of skimming strategy improve the students' reading ability. There was improvement on the students' average score. The students' average score in the pretest was 79.5. It had not achieved the criteria of success. After there was action of skimming strategy, the students' average score in the posttest was 89 . The increase of posttest score compared with the pretest was 9.5 points. So it had fulfilled the criteria of success at 80. After the skimming strategy was implemented in the experimental class, the mean score of experimental class was better that the mean score of control class. However, By using SPSS, it was found that the value in the Sig. (2-tailed) is above 0.05, it meant that there was not a statistically significant difference in the mean scores for control and experimental class.

The skimming strategy could also increase students'ability in comprehending reading text material, it could be seen in the result of reading test score. The use of skimming strategy could also improve students' participation in class discussion as it has shown in the result of observation. The students also had high motivation, it encouraged the students to learn more about reading. Since the skimming strategy brought positive influence toward students' reading ability, the teacher needed this skimming strategy to be implemented in teaching and learning process.

\section{REFERENCES}

Abdelrahman, M. \& Bsarah, M. (2014). The effect of reading strategies on developing reading comprehension among the $2 \mathrm{nd}$ secondary students in English language. English Language Teaching, 7(6).

Brown, H. D. (2004). Language Assessment: Principles and Classroom Practice. New York: Longman.

Creswell, J. W. (2012). Educational Research: Planning, Conducting, Evaluating Quantitative and Qualitative Research. Boston: Pearson Education, Inc. 
194 Celt: A Journal of Culture, English Language Teaching \& Literature, Volume 20, Number 1, June 2020, pp. 184 - 194

Fry, E. B. (2000) Reading Drills. http://goodcsr.in/cgibin/reading.php?article=reading_drills_edward_b_fry_2000_39_pages_re ading_pdf\& code $=0 d 14080$ c488cb36c137941f7e32881ee

Graddol, D. (2000). The Future of English. UK: The British Council.

Hutabarat, B, J. W. (2012) The Effect of Applying Skimming Technique on Grade XI Students Reading Comptrehension. Undergraduate thesis . Universitas Negeri Medan. http://digilib.unimed.ac.id/15761/

Miles, M.B., Huberman, A.M. \& Saldana, D. (2014). Qualitative Data Analysis: A Methods Sourcebook. USA: Sage Publication, Inc.

Patmawati, S. (2013). The Implementation of Skimming and Scanning Techniques in Teaching Reading in Junior High School (Unpublished master's thesis). Universitas Negeri Surabaya.

Windayani, K., Sundari, S. \& Ariyanto, S. (2014). Improving the Eight Grade Students' Reading Comprehension Achievement by Using Skimming and Scanning Techniques at MTs N 1 Jember. UNEJ Jurnal, 1(1): 1-5 http://repository.unej.ac.id/bitstream/handle/123456789/68434/KUR NIASARI\%20WINDAYANI.pdf?sequence $=1 \&$ isAllowed $=\mathrm{y}$. 